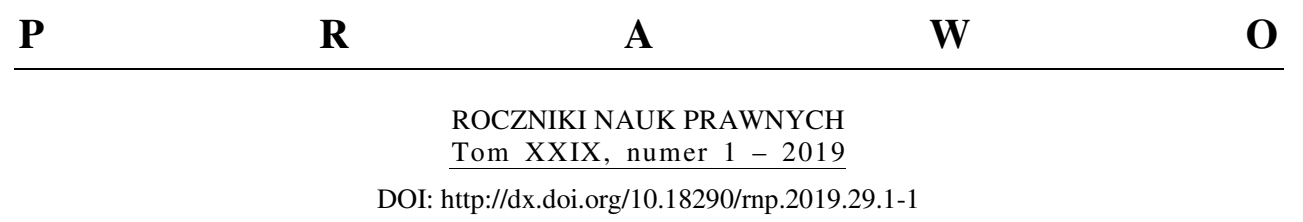

WERONIKA BATORY

\title{
DOBRA OSOBISTE I ICH OCHRONA NA GRUNCIE KODEKSU CYWILNEGO
}

\section{WSTĘP}

Naruszanie dóbr osobistych w XXI w. jest zjawiskiem powszechnym i stale nasilającym się. Jednym z powodów takiego stanu rzeczy jest coraz szybszy rozwój technologiczny, ułatwiający dostęp do zdobyczy techniki dużo większej liczbie osób niż kilkanaście czy kilkadziesiąt lat temu. Pojawienie się w codziennym życiu mediów społecznościowych, portali internetowych, telewizji i prasy w dużym stopniu ułatwiło możliwość rozpowszechniania nieprawdziwych informacji, wyrażania opinii godzących w dobra osobiste innych, udostępnianie wiadomości o życiu prywatnym czy intymnym wbrew woli poszkodowanych. W związku z tym, na gruncie prawa powstaje wiele kwestii spornych czy dane zachowanie można uznać za naruszenie dobra osobistego czy też nie. Zapewnienie skutecznej ochrony dóbr osobistych jest dzisiaj jednym z najważniejszych wyzwań dla ustawodawcy. Dobra osobiste w Polsce chronione są przez różnorodne akty normatywne, począwszy od Konstytucji przez prawo cywilne, prawo karne, prawo pracy aż po prawo autorskie. Podstawową ochronę dóbr zapewnia prawo karne, które dominuje wśród wybieranych przez poszkodowanych wariantów ochrony. Ciężko uzasadnić to zjawisko biorąc pod uwagę, że katalog dóbr osobistych chronionych przez prawo karne jest w swoim zakresie dużo węższy niż w przypadku ochrony przewidzianej na gruncie Kodeksu cywilnego. Dodatkowo jest on katalogiem zamkniętym. Ochrona zapewniona przez prawo cywilne obej-

Mgr Weronika BAtory - doktorant w Instytucie Nauk Prawnych Polskiej Akademii Nauk, ul. Nowy Świat 72, 00-330 Warszawa; e-mail: w.batory@doktorant.inp.pan.pl; https://orcid.org/ 0000-0002-4128-6979 
muje wszelkie dobra osobiste, również takie, które trudno jednoznacznie określić lub nazwać, dzięki czemu można uznać ją za bardziej elastyczną w zakresie interpretacji. Ochrona cywilnoprawna przyznaje możliwość dochodzenia roszczenia przez poszkodowanego również w sytuacji wystąpienia samego zagrożenia naruszenia dobra osobistego, w przeciwieństwie do sankcji karnych, w których ochrona przysługuje wyłącznie w przypadku naruszeń dokonanych. Jednocześnie roszczenia zawarte w Kodeksie cywilnym nie ulegają przedawnieniu, co czyni tę formę ochrony bardziej funkcjonalną ${ }^{1}$.

Niniejsza praca opiera się na rozważaniach na temat aktualnych rozwiązań prawnych dotyczących ochrony dóbr osobistych, możliwych roszczeń przewidzianych przez prawo cywilne w przypadku ich naruszenia, a także na wyjaśnieniu i charakterystyce istoty dóbr osobistych.

Głównym powodem wgłębienia się w zagadnienia dotyczące ochrony dóbr osobistych, była chęć zaczerpnięcia wiedzy na temat funkcjonowania owej ochrony oraz konstrukcji przepisów prawnych zawartych w Kodeksie cywilnym.

\section{RYS HISTORYCZNY}

Wprowadzenie instytucji ochrony dóbr osobistych zapoczątkowane zostało przez prawo rzymskie. Zawarte w nim było pojęcie nietykalności fizycznej, ochrony godności, czci oraz dobrego imienia. Kwestie te po raz pierwszy unormowała Ustawa XII tablic. Przed wprowadzoną ochroną, ówczesna Europa znała jedynie obronę swoich praw przez zastosowanie krwawej zemsty, która ukształtowała się w społeczeństwie jako reakcja na powszechnie nieakceptowane wyrządzenie zła. Reguła występująca w Ustawie XII tablic przewidywała odpowiedzialność za naruszenie nietykalności cielesnej. Do ubiegania się o ochronę uprawniony był zwierzchnik rodzinny, zarówno gdy chodziło o niego samego, jak i o jego dzieci, żonę czy też niewolnika².

W związku z tym, że Polska nigdy nie znajdowała się pod panowaniem rzymskim, nie posługiwała się bezpośrednio ochroną wynikającą z rzymskiej tradycji prawnej. Jednakże prawo rzymskie wbrew pozorom było w Polsce znane i miało wpływ na zbliżenie się do tradycji zachodniej poprzez przyjęcie chrztu w obrządku rzymskim. Główną cechą charakterystyczną w dawnym prawie polskim było

\footnotetext{
${ }^{1}$ A. CISEK, Dobra osobiste i ich niemajatkowa ochrona $w$ kodeksie cywilnym, Wrocław: Wydawnictwo Uniwersytetu Wrocławskiego 1989, s. 3-4.

${ }^{2}$ K. RATAJ, Ukształtowanie dóbr osobistych $i$ ich historyczny rozwój, [w:] Dobra osobiste, red. I. Lewandowska-Malec, Warszawa: Wydawnictwo C.H. Beck 2017, s. 3.
} 
oparcie norm prawnych na zwyczajach. Jednym z takich zwyczajów była krwawa zemsta, uznawana w okresie rodowym i określana jako prawo jednostki do podjęcia odwetu. W średniowieczu próbowano jej zakazać i zastąpić karą zadośćuczynienia w postaci prywatnej opłaty płaconej osobie poszkodowanej lub innym członkom rodziny. Kara ta była pierwotną formą współczesnego zadośćuczynienia. Następnie w XIII w. na podstawie Księgi elbląskiej, która była najstarszym zbiorem praw, zróżnicowano kary prywatne biorąc pod uwagę status społeczny osoby poszkodowanej.

Rozwiązanie to podtrzymane zostało również w Statucie małopolskim i wielkopolskim. Do przestępstw ściganych w ramach skargi prywatnej zaliczano mężobójstwo oraz obrazę czci przejawiającą się w znieważeniu osoby słowami obraźliwymi. W czasie rozbiorów Polski wprowadzono nowe systemy prawne na poszczególnych terytoriach podzielonego kraju, uzależnione od porządków prawnych występujących w krajach zaborczych. Na obszarze centralnej i wschodniej Polski obowiązywał Kodeks Napoleona oraz ustawy hipoteczne, Kodeks Cywilny Królestwa Polskiego z 1825 r. oraz ukaz o związku małżeństwa z 1836 r. W przypadku ziem zaboru pruskiego aktem obowiązującym był Landrecht pruski, który został zastąpiony przez niemiecki kodeks cywilny. Na Kresach wschodnich obowiązywało rosyjskie prawo cywilne. Na terenach byłej Galicji obowiązywał ABGB - austriacki kodeks cywilny. W okresie międzywojennym działalność ustawodawcza była bardzo intensywna i swoim zakresem objęła również zagadnienia dotyczące ochrony dóbr osobistych. Opierały się one na konstrukcji praw podmiotowych oraz idei praw na dobrach niematerialnych.

Jedną z pierwszych ustaw regulujących zagadnienia ochrony dóbr osobistych była ustawa o prawie autorskiem z dnia 29 marca 1926 r. ${ }^{3} \mathrm{~W}$ niej po raz pierwszy zastosowano pojęcie praw osobistych przysługujących twórcy. Przepis art. 62 omawianej ustawy wprowadzał możliwość wystąpienia przez twórcę z roszczeniem o zaniechanie i usunięcie skutków czynów krzywdzących, m.in. w formie deklaracji publicznej lub odwołania, ogłoszenia wyroku w czasopiśmie lub innego rodzaju zadośćuczynienia. Oprócz roszczeń o charakterze niemajątkowym, twórcy przysługiwało również prawo żądania pokutnego, gdy wina naruszającego była umyślna oraz naprawienie szkód majątkowych wynikających z naruszenia praw osobistych. Art. 63 ustawy przewidywał możliwość występowania z powództwem po śmierci twórcy przez osoby wskazane przez niego za życia. Jeżeli tego nie uczynił, osobami uprawnionymi byli rodzice, małżonek, zstępni, a także jego bracia i siostry. Mogli oni występować z roszczeniami o charakterze

\footnotetext{
${ }^{3}$ Ustawa z dnia 29 marca 1926 r. o prawie autorskiem, Dz. U. Nr 48, poz. 286.
} 
niemajątkowym, co oznaczało, że niemożliwe było ubieganie się przez nich o pokutne. Wprowadzenie omawianego przepisu było ewenementem na skalę europejską oraz zrodziło szereg pytań dotyczących pogodzenia nowego rozwiązania z przyjmowaną dotychczas zasadą opierającą się na niezbywalności praw osobistych ${ }^{4}$.

Kolejnym aktem normatywnym, który nawiązywał do koncepcji szerokiej ochrony praw osobistych była ustawa z dnia 2 sierpnia 1926 r. o zwalczaniu nieuczciwej konkurencji ${ }^{5}$. W zamyśle ustawa ta miała chronić prawa przedsiębiorcy, a ochrona miała być realizowana $\mathrm{z}$ uwzględnieniem prawa podmiotowego bezwzględnego o charakterze majątkowym. Interesy majątkowe przedsiębiorcy chronione były przed „wdzieraniem się w klientelę”, które miało postać rozpowszechniania nieprawdziwych lub oczerniających informacji. Obok przysługujących roszczeń w zakresie majątkowym, ustawa przyznawała również roszczenia niemajątkowe w postaci zaniechania i usunięcia przyczyn mogących wywołać u odbiorców mylne wrażenie.

Następnym aktem, który regulował problematykę dóbr osobistych było rozporządzenie Prezydenta RP z dnia 22 marca 1928 r. o ochronie wynalazków, wzorów i znaków towarowych ${ }^{6}$. Realizacja ochrony dóbr osobistych następowała wyłącznie w przypadku wkroczenia w sferę wyłączności prawa chronionego $\mathrm{w}$ formie paten$\mathrm{tu}^{7}$. Aktem normatywnym, który wpłynął na rozwój niemajątkowej koncepcji ochrony dóbr osobistych był Kodeks zobowiązań ${ }^{8}$. Uchwalenie kodeksu zobowiązań spowodowało derogację obowiązującego ówcześnie na ziemiach polskich ustawodawstwa dzielnicowego 9 . Ochrona dóbr osobistych po II wojnie światowej kształtowała się m.in. w licznych projektach kodeksu cywilnego. W owym czasie coraz silniej postulowano potrzebę kompleksowego unormowania zagadnienia, jakim była ochrona dóbr osobistych. Jedną z ważniejszych prób było uchwalenie w 1950 r. przepisów ogólnych prawa cywilnego, którego art. 11 i art. 39 stworzyły podstawę obecnie obowiązujących unormowań ${ }^{10}$.

\footnotetext{
${ }^{4}$ CISEK, Dobra osobiste i ich niemajatkowa ochrona, s. 18.

${ }^{5}$ Ustawa z dnia 2 sierpnia 1926 r. o zwalczaniu nieuczciwej konkurencji, Dz. U. Nr 96, poz. 559.

${ }^{6}$ Rozporządzenie Prezydenta Rzeczypospolitej z dnia 22 marca 1928 r. o ochronie wynalazków, wzorów i znaków towarowych, Dz. U. Nr 39, poz. 384.

${ }^{7}$ W. BATORY, Stulecie rozwoju ochrony patentowej na ziemiach polskich - analiza historycznoprawna od 1918 roku do okresu bieżacego, Polska Niepodległa 1918-2018. Księga rocznicowa z okazji 100 rocznicy odzyskania niepodległości, red. A. Wiśniewski, Warszawa: Wydawnictwo Think \& Make 2018, s. 625.

${ }^{8}$ Rozporządzenie Prezydenta Rzeczypospolitej z dnia 27 października 1933 r. - Kodeks zobowiązań, Dz. U. Nr 82, poz. 598.

${ }^{9}$ CISEK, Dobra osobiste i ich niemajątkowa ochrona, s. 25.

${ }^{10}$ Ustawa z dnia 18 lipca 1950 r. - Przepisy ogólne prawa cywilnego, Dz. U. Nr 34, poz. 311.
} 


\section{CHARAKTER PRAWNY DÓBR OSOBISTYCH}

W polskim prawie nie występuje legalna definicja dóbr osobistych. W art. 23 Kodeksu cywilnego zawarty jest jedynie otwarty katalog dóbr, które podlegają prawnej ochronie ${ }^{11}$. Według tego przepisu, pod ochroną prawa cywilnego niezależnie od ochrony przewidzianej w innych przepisach znajdują się dobra osobiste, w szczególności takie jak: zdrowie, wolność, cześć, swoboda sumienia, nazwisko lub pseudonim, wizerunek, tajemnica korespondencji, nietykalność mieszkania, twórczość naukowa, artystyczna, wynalazcza i racjonalizatorska. Autor artykułu Problem twórczej wykładni przepisów o ochronie dóbr osobistych P. Sut doszukuje się braku definicji dobra osobistego w niemożności uogólnienia tego pojęcia, które jest każdorazowo konkretyzowane przez osoby dokonujące jego interpretacji. Zapewnia to podmiotom luz decyzyjny. Konsekwencją takiego stanu rzeczy jest zobligowanie organów do objęcia ochroną tych dóbr, które nie są wyrażone wprost $\mathrm{w}$ tej definicji ${ }^{12}$.

Według S. Grzybowskiego, dobrem osobistym są indywidualne wartości świata uczuć oraz stanu psychicznego człowieka ${ }^{13}$. Skutkiem powiększającej się ilości wydawanych orzeczeń w tym zakresie jest rozszerzenie katalogu dóbr osobistych. Przykładem tego zjawiska jest wyrok Sądu Najwyższego z dnia 18 stycznia 1984 r., który wyraźnie wskazał, że dobrem osobistym podlegającym ochronie są również dobra związane ze strefą życia intymnego, prywatnego oraz rodzinnego ${ }^{14}$. Mimo, że treść art. 23 Kodeksu cywilnego zawiera podstawowe chronione dobra osobiste, nie zostało w nim wymienione najważniejsze dobro, jakim jest życie człowieka. Ochrona życia ludzkiego jest uwzględniona bezpośrednio w art. 38 Konstytucji Rzeczpospolitej Polskiej ${ }^{15}$. Środki przysługujące ochronie życia przede wszystkim mają charakter karnoprawny, natomiast na gruncie prawa cywilnego przyjmują one postać roszczenia prewencyjnego, jakim jest żądanie zaprzestania zachowań stwarzających zagrożenie dla życia ${ }^{16}$. Sąd Najwyższy w orzeczeniu z 10 czerwca 1977 r. wypracował definicję dobra osobistego, jako ogół czynników mających na celu

\footnotetext{
${ }^{11}$ Ustawa z dnia 23 kwietnia 1964 r. - Kodeks cywilny, Dz. U. Nr 16, poz. 93 [dalej cyt.: Kodeks cywilny].

${ }^{12}$ P. SUT, Problem twórczej wykładni przepisów o ochronie dóbr osobistych, „Państwo i Prawo” 9 (1997), s. 30.

${ }^{13}$ S. GRZYBOwSKI, Ochrona dóbr osobistych wedtug przepisów ogólnych prawa cywilnego, Warszawa: Wydawnictwo Prawnicze 1957, s. 78.

${ }^{14}$ Wyrok Sądu Najwyższego z dnia 18 stycznia 1984 r., sygn. akt I CR 400/83, OSNC 184/11/195.

${ }^{15}$ Konstytucja Rzeczypospolitej Polskiej z dnia 2 kwietnia 1997 r., Dz. U. Nr 78, poz. 483.

${ }^{16}$ P. Sobolewski, Dobra osobiste, [w:] Kodeks cywilny. Komentarz. Tom I, red. K. Osajda, Warszawa: Wydawnictwo C.H. Beck 2013, s. 391.
} 
zapewnienie obywatelowi rozwoju jego osobowości, ochronę jego egzystencji i zapewnienie mu prawa do korzystania z tych dóbr, które są dostępne na danym etapie rozwoju społeczno-ekonomicznego społeczeństwa, a które sprzyjają zachowaniu cech odrębności i związaniu ze społeczeństwem, w którym żyje ${ }^{17}$.

Jednym z pierwszych Autorów w Polsce, którzy zmierzyli się ze zdefiniowaniem pojęcia „dobra osobistego” był F. Zoll. W początkowych latach XX w. przyjął, że jest to prawo podmiotowe, które polega na zachowaniu przez podmiot wolności i nietykalności osobistej rozumianej zarówno w sferze fizycznej, jak i psychicznej. Uważał, że dobra osobiste cechują się brakiem przedmiotu, nierozerwalną więzią z podmiotem, posiadaniem wartości niemajątkowej oraz niemożnością ustawowego określenia ich rozciągłości. Stwierdził również, że przedmiotem dobra osobistego jest tak naprawdę sam człowiek.

Drugim Autorem, który podjął się scharakteryzowania dóbr osobistych był S. Grzybowski. Przedstawiał jednak inne założenie niż F. Zoll. Reprezentował koncepcję subiektywistyczną polegającą na uzależnieniu istnienia dobra osobistego od osobistego odczucia podmiotu i jego indywidualnego przekonania. Jednakże uzależnianie istnienia dobra osobistego od wewnętrznych przekonań mogłoby tworzyć znaczne trudności podczas orzekania w sprawie przez sąd. W praktyce naruszenie dobra osobistego byłoby uzależnione wyłącznie od osobistego przekonania podmiotu, skutkiem czego weryfikacja wystąpienia takiego naruszenia przez organy władzy sądowniczej byłaby niemożliwa. Dlatego też pogląd S. Grzybowskiego nie znalazł zwolenników. Osobą, która podzieliła jego zdanie był jedynie A. Wolter ${ }^{18}$. W praktyce koncepcja subiektywistyczna została uznana za niewłaściwą. Wśród przedstawicieli doktryny panuje powszechne przekonanie, że naruszenie dobra osobistego powinno być rozpatrywane na podstawie obiektywnych kryteriów, poprzez wyraz społecznej aprobaty dla ochrony konkretnej wartości oraz negatywnej oceny zachowania osoby naruszającej tą wartość. Tę tezę potwierdza wyrok Sądu Najwyższego, który orzekając w sprawie dotyczącej naruszenia dobra osobistego potwierdził zasadność uzależnienia oceny naruszenia od obiektywnej reakcji opinii publicznej ${ }^{19}$.

Cechą charakterystyczną dóbr osobistych jest ich bezwzględność, czyli skuteczność erga omnes. Oznacza to obowiązek powstrzymania takich zachowań przez inne podmioty, które mogłyby być uznane za naruszające lub zagrażające tym uprawnieniom. Dobra osobiste wyróżniają się również tym, że mają charakter

\footnotetext{
${ }^{17}$ Wyrok Sądu Najwyższego z dnia 10 czerwca 1977 r., sygn. akt II CR 187/77.

${ }^{18}$ A. PuchaŁa, Pojęcie dóbr osobistych, [w:] Dobra osobiste, s. 28.

${ }^{19}$ Wyrok Sądu Najwyższego z dnia 19 września 1968 r., sygn. akt II CR 291/68, OSNCPiUS 1969.
} 
niemajątkowy. Oznacza to, iż niemożliwe jest wyrażenie ich w pieniądzu ani nadanie im ekonomicznej wartości. Stanowi o tym art. 448 Kodeksu cywilnego. Jednocześnie nie oznacza to, że reperkusje związane z ich naruszeniem nie mogą odbijać się w sferze majątkowej. W związku z tą cechą należy jednocześnie wspomnieć o zjawisku, jakim jest komercjalizacja dóbr osobistych, m.in. wizerunku, nazwiska czy czci. Przejawia się on w uzyskiwaniu samoistnej wartości ekonomicznej przez te dobra oraz stawaniem się przedmiotem obrotu majątkowego ${ }^{20}$.

Dobra osobiste powstają w momencie narodzin człowieka oraz gasną w chwili jego śmierci ${ }^{21}$. Sam fakt zaistnienia zdarzenia, jakim są narodziny człowieka powoduje, że przysługuje mu możliwość domagania się ich ochrony. Niektórzy Autorzy specjalizujący się w zagadnieniu dóbr osobistych uważają, że wybrane dobra osobiste przysługują zmarłemu i nie wygasają ze śmiercią człowieka. Chodzi tutaj przede wszystkim o dobra związane z twórczością zmarłego czy też z kultem pamięci osób zmarłych. Pewne kategorie dóbr osobistych są nabywane w wyniku następstw określonych działań lub są związane z uczestnictwem w określonych stosunkach rodzinnych lub społecznych. Do tej kategorii można zaliczyć dobra związane z działalnością twórczą lub z tajemnicą przysposobienia. Niemożliwe jest przeniesienie dóbr osobistych na inne osoby, ponieważ są one związane ściśle $\mathrm{z}$ danym podmiotem i nie dają się od niego oddzielić ${ }^{22}$.

$\mathrm{Na}$ podstawie art. 43 Kodeksu cywilnego osobom prawnym przysługuje ochrona dóbr osobistych na takich samych zasadach jak osobom fizycznym. Dobrami osobistymi osoby prawnej są takie wartości niemajątkowe, które pozwalają jej na funkcjonowanie zgodne ze swoim zakresem działania. Jednocześnie należy podkreślić, że osoby prawne z samej swej istoty nie posiadają niektórych dóbr osobistych takich jak na przykład wizerunek. Jak wskazuje w orzeczeniu Sąd Najwyższy, wizerunkiem osoby prawnej nie jest ani wizerunek miejsca jej siedziby, ani wizerunki osób, które wchodzą w skład jej organów ${ }^{23}$. W związku z odesłaniem z art. $331 \S 1$ Kodeksu cywilnego przepisy dotyczące dóbr odnoszą się również do tzw. ,ułomnych osób prawnych"24.

\footnotetext{
${ }^{20}$ J. PiĄTOwski, Pojęcie spadku i jego zakres, [w:] System prawa cywilnego. Prawo spadkowe, red. J. Piątowski, Wrocław: Wydawnictwo Polskiej Akademii Nauk 1976, s. 50.

${ }^{21}$ PuChata, Dobra osobiste, s. 30.

${ }^{22}$ CISEK, Dobra osobiste i ich niemajatkowa ochrona, s. 43.

${ }^{23}$ Wyrok Sądu Najwyższego z dnia 25 maja 1977 r., sygn. akt I CR 159/77.

${ }^{24}$ SobOLEWSKI, Kodeks cywilny. Komentarz, s. 455.
} 


\section{OCHRONA DÓBR OSOBISTYCH NA GRUNCIE PRAWA CYWILNEGO}

Ustawodawca w art. $24 \S 1$ Kodeksu cywilnego wyraźnie wskazuje, że ochrona dóbr osobistych przysługuje w momencie wystąpienia zagrożenia tego dobra cudzym działaniem, które musi być bezprawne. $\mathrm{Z}$ powyższego należy wywnioskować, że samo zdarzenie, jakim jest zagrożenie wystąpienia danego działania (w tym przypadku chodzi o zagrożenie wystąpienia działania naruszającego dobro osobiste) uprawnia do dochodzenia roszczenia o zaniechanie tego działania. Według orzecznictwa Sądu Najwyższego bezprawnym zachowaniem można nazwać takie działanie, które jest sprzeczne z prawem lub z zasadami współżycia społecznego $^{25}$. Istotne jest, aby obawa naruszenia przedstawiona została w sposób obiektywny i jak najbardziej realny, ponieważ jak wskazuje orzecznictwo Sądu Najwyższego ocena stanowiąca, czy w konkretnej sytuacji doszło do naruszenia dobra osobistego nie może być przeprowadzona wyłącznie na podstawie subiektywnego przekonania poszkodowanego. Kryteria brane pod uwagę przy ocenianiu bezprawności powinny być poddane obiektywizacji m.in. poprzez uwzględnienie odczuć szerszego grona uczestników oraz norm postępowania takich jak normy obyczajowe lub związane z tradycją.

$\mathrm{W}$ związku $\mathrm{z}$ tym, że $\mathrm{w}$ analizowanym przepisie ustawodawca wprowadził domniemanie bezprawności, podmiotem na którym ciąży obowiązek udowodnienia, że działanie nie było bezprawne jest osoba pozwana. Osoba taka może skutecznie się ekskulpować, jeżeli wykaże, że jej działanie nie posiada znamion bezprawności. W przypadku udowodnienia przez pozwanego, że działał w obronie uzasadnionego interesu nie można mówić o odpowiedzialności za naruszenie dóbr osobistych poszkodowanego $^{26}$. Pomimo tego, że ustawodawca posłużył się w tej konstrukcji prawnej pojęciem działania, należy podkreślić, że zaniechanie może również doprowadzić do naruszenia lub zagrożenia dóbr osobistych. Przykładem takiego zachowania może być zaniechanie usunięcia informacji obraźliwej lub zniesławiającej na tablicy ogłoszeń. Przepis ten nie wprowadza wyłączeń w zakresie katalogu podmiotów mogących naruszyć dobra osobiste, przez co zaliczyć do nich można zarówno osoby fizyczne, jak i osoby prawne. Ze względu na to, że czynność ta jest czynnością faktyczną a nie prawną, nie ma znaczenia czy naruszający posiada zdolność do czynności prawnej czy też nie. Odpowiedzialność za naruszenie dobra osobistego może ponieść zarówno osoba prawna, jak i członek

\footnotetext{
${ }^{25}$ Wyrok Sądu Najwyższego z dnia 25 października 1982 r., sygn. akt I CR 239/82.

${ }^{26}$ S. Kalus, Osoby. Przestanki ochrony, [w:] Kodeks cywilny. Komentarz. Tom I, red. M. Habdas, M. Fras, Warszawa: Wolters Kluwer 2018, s. 127-129.
} 
jej organu. Z punktu widzenia praktycznego niezwykle ciężkie jest rozstrzygnięcie, kiedy odpowiedzialność za naruszenie dobra ponosi samodzielnie członek organu osoby prawnej, a kiedy skutki tego naruszenia mogą być przypisane osobie prawnej. Ze względu na różne stanowiska Sądu Najwyższego w tej kwestii, rozważając taką sytuację powinno się ocenić czy zachowanie o charakterze naruszającym dobro osobiste poszkodowanego stanowiło realizację kompetencji organu osoby prawnej czy było wyłącznie sformułowaniem własnej opinii ${ }^{27}$.

Drugim roszczeniem, które poszkodowany ma prawo żądać jest dopełnienie czynności potrzebnych do usunięcia jego skutków. W szczególności może być to złożenie oświadczenia o odpowiedniej treści i w odpowiedniej formie w postaci sprostowania w gazecie lub przeprosin. Czynności te powinny przynieść satysfakcję osobie pokrzywdzonej, a także przeciwdziałać takim naruszeniom w przyszłości. Pokrzywdzony powinien również sprecyzować treść tego oświadczenia występując z żądaniem jego złożenia. Sąd Apelacyjny w Krakowie w jednym z wyroków orzekł, że przepis ten pozostawia ocenie sądu, czy sprecyzowana treść oświadczenia żądanego przez pokrzywdzonego jest odpowiednia do usunięcia skutków naruszenia ${ }^{28}$.

Kolejnym środkiem ochrony o charakterze niemajątkowym jest powództwo o ustalenie przysługujące na podstawie art. 189 Kodeksu postępowania cywilnego. Według orzeczenia Sądu Najwyższego, powództwo o ustalenie stosunku istnienia prawa ma wyłącznie charakter subsydiarny w stosunku do innych środków ochrony $^{29}$. Uprawnienie to przysługuje w momencie, w którym zainteresowany nie ma możliwości dochodzenia swoich praw na podstawie innych instrumentów prawnych lub gdy roszczenia $\mathrm{z}$ art. 24 Kodeksu cywilnego będą niewystarczające. Przesłanką do wytoczenia powództwa na podstawie powyższego przepisu jest posiadanie interesu prawnego przez powoda.

Środki ochrony dóbr osobistych o charakterze niemajątkowym mogą być dochodzone łącznie wraz z roszczeniami o charakterze majątkowym. Na zasadach przewidzianych w Kodeksie poszkodowany może ubiegać się o zadośćuczynienie pieniężne lub zapłatę odpowiedniej sumy pieniężnej na wskazany cel społeczny. Jeżeli wskutek naruszenia dobra osobistego została wyrządzona również szkoda majątkowa, można żądać jej naprawienia na zasadach ogólnych. Dla roszczeń majątkowych podstawę prawną stanowią przepisy art. 415 Kodeksu cywilnego (dla odszkodowania) oraz przepisy art. 445 i art. 448 Kodeksu cywilnego w zakre-

\footnotetext{
${ }^{27}$ SoBOLEWSKI, Kodeks cywilny. Komentarz, s. 409.

${ }^{28}$ Wyrok Sądu Apelacyjnego w Krakowie z dnia 28 kwietnia 2016 r., sygn. akt I ACa 1846/15.

${ }^{29}$ Wyrok Sądu Najwyższego z dnia 29 października 2009 r., sygn. akt III CZP 79/09.
} 
sie zadośćuczynienia. Art. 445 w swoim zakresie przewiduje zadośćuczynienie jedynie $\mathrm{w}$ określonych przypadkach naruszenia dóbr osobistych takich jak uszkodzenie ciała, wywołanie rozstroju zdrowia, pozbawienie wolności, skłonienie za pomocą podstępu, gwałtu lub nadużycia stosunku zależności do poddania się czynowi nierządnemu. Zadośćuczynienie ma charakter całościowy. Sąd podczas orzekania o wysokości zadośćuczynienia bierze pod uwagę wszystkie elementy mogące mieć wpływ na rozmiar doznanej szkody. W omawianym artykule zawarte jest pojęcie przyznania „odpowiedniej sumy tytułem zadośćuczynienia”, które jest pojęciem lakonicznym, jednakże nie pozostawia wątpliwości, że takie ujęcie miało na celu wypracowanie w praktyce bardziej szczegółowych zasad uzależnionych od konkretnej sytuacji czy też stopnia doznanej krzywdy. Głównym celem wprowadzenia instytucji zadośćuczynienia było wyrównanie szkód emocjonalnych oraz fizycznych poszkodowanego. Powinno ono mieć postać rekompensaty za doznaną krzywdę. Przy jego orzekaniu sąd powinien w taki sposób rozpatrzyć sprawę, aby przyznana kwota nie stała się źródłem wzbogacenia osoby poszkodowanej. Sąd Najwyższy uznał, że zadośćuczynienie nie jest karą, a sposobem na naprawienie krzywdy wyrządzonej poszkodowanemu ${ }^{30}$. Pod pojęciem doznanej krzywdy znajduje się zarówno odczuwane cierpienie fizyczne takie jak ból, jak również psychiczne związane $\mathrm{z}$ uczuciami przeżywanymi w związku z rozstrojem zdrowia np. wstydem czy wyłączeniem z normalnego życia. W związku z tym, że przyznanie odszkodowania i jego wysokości ma charakter ocenny, sędziowie zachowują dużą swobodę przy jego orzekaniu. Nie jest to jednak jednoznaczne z uznaniem dowolnym, ponieważ sądy w oparciu o rozmiar doznanej krzywdy powinny orzekać zgodnie z przepisami biorąc pod uwagę, że decyzje w zakresie wymiaru należnej dla zadośćuczynienia kwoty należą do sfery swobodnego uznania sędziowskiego. Przy jego orzekaniu należy brać pod uwagę zarówno rozmiar wyrządzonej krzywdy, jak i widoki na przyszłość poszkodowanego.

Art. 448 Kodeksu cywilnego odnosi się konkretnie do zadośćuczynienia w przypadku naruszenia dóbr osobistych. Przyjmuje się, że powyższy artykuł ma zastosowanie do wszystkich możliwych dóbr osobistych, nawet tych, które nie zostały wymienione w ustawie. Przepis ten uprawnia poszkodowanego do domagania się odpowiedniej sumy tytułem zadośćuczynienia pieniężnego za doznaną krzywdę lub do żądania zasądzenia odpowiedniej sumy pieniężnej na wskazany cel społeczny. Aby roszczenie było zasadne, dobro osobiste musi być naruszone w sposób bezprawny. Ciężar dowodu okoliczności wpływających na wysokość żądanego świadczenia $w$ istocie spoczywa tu na powodzie. $W$ orzecznictwie dominuje pogląd, w którym poza przesłanką bezprawności musi wystąpić wina

\footnotetext{
${ }^{30}$ Wyrok Sądu Najwyższego z dnia 3 lutego 2000 r., sygn. akt I CKN 969/98.
} 
sprawcy naruszenia niezależnie od tego, czy była ona umyślna czy nieumyślna. $\mathrm{Z}$ roszczeniem takim może wystąpić każda osoba fizyczna, jeżeli była bezpośrednio pokrzywdzona. Jak wskazuje praktyka orzecznicza, dochodzenie tego roszczenia o zadośćuczynienie może być dochodzone również przez najbliższych członków rodziny zmarłego, gdy śmierć nastąpiła na skutek deliktu, który miał miejsce przed dniem 3 sierpnia 2008 r. Powyższe rozwiązanie miało związek z nowelizacją Kodeksu cywilnego. Ustawą z dnia 30 maja 2008 r. do art. 446 Kodeksu cywilnego dodano $§ 4$. Podstawą takiego roszczenia $\mathrm{z}$ art. 448., związanego ze śmiercią osoby bliskiej, nie jest sam fakt śmierci osoby bliskiej, ale naruszenie konkretnego dobra osobistego ${ }^{31}$.

Wątpliwości nauki prawa cywilnego w zakresie art. 448 Kodeksu cywilnego odnoszą się do potencjalnych przesłanek dochodzenia roszczenia. Sąd Apelacyjny w Warszawie podjął się analizy, czy przesłanką do uzyskania zadośćuczynienia z przepisu art. 448 Kodeksu cywilnego może być naruszenie dobra osobistego na skutek uporczywego nękania oraz zastraszania dłużnika przez wierzyciela. Podsumowując powyższy wyrok, sąd stwierdził, że przypadku gdy czynności związane z zaspokojeniem wierzyciela charakteryzują się nękaniem (chodzi tutaj o zachowania takie jak np. czynności windykacyjne pracowników pozwanego polegające na wielokrotnym kierowaniu do powoda wezwań do zapłaty w wiadomościach SMS i w rozmowach telefonicznych w porze nocnej), to zachowania te muszą zostać ocenione jako zawinione naruszenie takich dóbr osobistych jak: godność, wolność, mir domowy, dobre imię czy też prywatność. Podejmowane czynności przez wierzycieli w postaci pojawiania się windykatorów w miejscu zamieszkania dłużnika, czy też intensywność kierowania komunikatów do dłużnika w formie pisemnej lub elektronicznej może również stanowić przesłankę naruszenia dóbr osobistych z powyższego artykułu ${ }^{32}$. Z kolei inne orzeczenie Sądu Apelacyjnego potwierdziło, że zerwanie więzi rodzinnych wskutek śmierci osoby bliskiej jest przyczyną doznania krzywdy, której doświadczenie zasługuje na ochronę przewidzianą w art. 448 w zw. z art. 24 Kodeksu cywilnego ${ }^{33}$.

Istotną tezą z punktu widzenia analizy kryteriów naruszenia dóbr osobistych osób prawnych powstałą w wyniku wydania wyroku Sądu Apelacyjnego w Katowicach jest stwierdzenie, że w przypadku naruszenia dóbr osobistych osób prawnych, decydujące oraz jedyne znaczenie mają wyłącznie obiektywne kryteria

\footnotetext{
${ }^{31}$ Wyrok Sądu Rejonowego Gdańsk-Południe w Gdańsku z dnia 29 czerwca 2017 r., sygn. akt I C $177 / 17$.

${ }^{32}$ Wyrok Sądu Apelacyjnego w Warszawie z dnia 11 października 2018 r., sygn akt I ACa $387 / 18$.

${ }^{33}$ Wyrok Sądu Apelacyjnego w Warszawie z dnia 10 maja 2018 r., sygn. akt V ACa 753/17.
} 
naruszenia dóbr. W przeciwieństwie do osób fizycznych, w przypadku których bierze się pod uwagę zarówno kryteria subiektywne, jak i obiektywne, osoby prawne nie mogą odczuwać tak jak ludzie wyrządzonej im krzywdy oraz wykluczone jest uwzględnianie ujemnych odczuć osób tworzących substrat osobowy osoby prawnej. Odczucia takie jak świadomość własnej wartości, czy też szacunek dla samego siebie nie mogą w ich przypadku znaleźć zastosowania ${ }^{34}$.

Rozmiar krzywdy poszkodowanego powinien być każdorazowo oceniany indywidualnie, jednakże nie bez znaczenia są motywy, którymi kieruje się sprawca naruszenia takiego dobra. Jeśli uczynił to z chęci zysku, poczucie krzywdy jest większe albowiem osoba pokrzywdzona czuje się wykorzystana przez sprawcę w celu pomnożenia jego majątku.

Jak wskazuje wyrok Sądu Apelacyjnego w Warszawie, wielkość zadośćuczynienia nie może być uzależniona ani od dochodów poszkodowanego ani od dochodów sprawcy, bowiem zadośćuczynienie w swej istocie nie pełni funkcji represyjnej. Uzależnienie zadośćuczynienia od sytuacji majątkowej poszkodowanego mogłoby prowadzić do dyskryminacji tych poszkodowanych, których sytuacja materialna jest gorsza i uprzywilejowania poszkodowanych, których zarobki są większe. Zadośćuczynienie pełni rolę kompensacyjną, zatem jego wysokość musi być odpowiednia do wysokości krzywdy doznanej przez poszkodowanego ${ }^{35}$.

Nie zawsze głównym motywem działania osoby poszkodowanej jest przyznanie jej odpowiedniej sumy zadośćuczynienia. Czasami większą satysfakcję poszkodowanemu przyniesie wpłata odpowiedniej sumy na wybrany cel społeczny. Warunki, które muszą być spełnione, aby roszczenie o zasądzenie kwoty było zasadne są takie same jak w sytuacji przyznania zadośćuczynienia. Takie rozstrzygnięcie sprawy zależne jest wyłącznie od woli pokrzywdzonego i nie zależy od swobodnej oceny sądu. W momencie uprawomocnienia się wyroku, instytucja społeczna nabywa uprawnienie do żądania spełnienia świadczenia od osoby uznanej za naruszającego.

Niejednokrotnie zdarza się, że konsekwencją naruszenia dobra osobistego jest jednoczesne spowodowanie uszczerbku w majątku poszkodowanego. Przykładem takiego działania może być konieczność rezygnacji z zatrudnienia, zakończenie prowadzenia lub spadek obrotów działalności w związku z naruszeniem takich dóbr osobistych jak zdrowie czy wizerunek. Roszczeniem, jakie Kodeks cywilny przewiduje w przypadku naruszenia dobra osobistego jest roszczenie o naprawie-

\footnotetext{
${ }^{34}$ Wyrok Sądu Apelacyjnego w Katowicach z dnia 25 kwietnia 2018 r., sygn. akt I ACa $1056 / 17$.

${ }^{35}$ Wyrok Sądu Apelacyjnego w Warszawie z dnia 11 lipca 2018 r., sygn. akt V ACa 565/17.
} 
nie wyrządzonej szkody majątkowej z art. $24 \S 2$. W takim przypadku Kodeks cywilny uprawnia poszkodowanego do ubiegania się o naprawienie szkody na zasadach ogólnych na podstawie art. 415 i następnych, a także na podstawie art. 361-363. Odszkodowanie na tej podstawie zostanie przyznane, jeżeli wystąpią niezbędne do jego rozpatrzenia przesłanki takie jak zawinione działanie lub zaniechanie, wystąpienie szkody oraz odpowiedniego związku przyczynowego między nimi. Konieczne jest również wykazanie wysokości poniesionej szkody, bowiem gdy wykazanie tej szkody jest niemożliwe lub utrudnione sąd może samodzielnie na podstawie rozważenia wszelkich okoliczności sprawy zasądzić sumę właściwą ${ }^{36}$.

Zgodnie z tym, co wcześniej zostało wspomniane, na podstawie art. 43 Kodeksu cywilnego, przepisy o ochronie dóbr osobistych osób fizycznych odnosi się jednocześnie do osób prawnych. Należy zauważyć, że kategoria dóbr osobistych, określonych $\mathrm{w}$ art. 23 i art. $24 \mathrm{w}$ związku z art. 43 Kodeksu cywilnego nie odnosi się do kategorii przedsiębiorców, a do podmiotów prawa cywilnego. Dobra osobiste osób prawnych - przedsiębiorców wynikają przede wszystkim z art. $55^{1} \mathrm{Ko}$ deksu cywilnego, w skład których wchodzi m.in. tajemnica korespondencji, dobre imię, tajemnica przedsiębiorstwa, nietykalność pomieszczeń oraz firma. Jak orzekł Sąd Najwyższy: „dobre imię osoby prawnej naruszają wypowiedzi, które obiektywnie oceniając, przypisują osobie prawnej niewłaściwe postępowanie mogące spowodować utratę do niej zaufania potrzebnego do prawidłowego funkcjonowania w zakresie swych zadań’ ${ }^{, 37}$. Oprócz ochrony występującej w Kodeksie cywilnym, należy podkreślić, że innymi przepisami zapewniającymi ochronę firmy przedsiębiorcy są regulacje zawarte w ustawie o zwalczaniu nieuczciwej konkurencji. Warto również zaznaczyć, iż spółce cywilnej nie przysługuje ochrona taka, jaką chronione są osoby fizyczne lub prawne, ponieważ nie można przyznać jej podmiotowości prawnej. Należy również wspomnieć o instytucji ochrony prawa do firmy w zakresie tzw. prawa firmowego. Jest to zespół norm wiążących się z tworzeniem oraz ochroną prawa do firmy. Należą do niego zarówno przepisy Kodeksu cywilnego, przepisy ustawy o zwalczaniu nieuczciwej konkurencji, jak i ustawy o krajowym rejestrze sądowym ${ }^{38}$.

\footnotetext{
${ }^{36}$ N. SKIBA, Ochrona dóbr osobistych na gruncie polskiego prawa cywilnego, [w:] Dobra osobiste, s. 250.

${ }^{37}$ Wyrok Sądu Najwyższego z dnia 9 czerwca 2005 r., sygn. akt III CK 622/04.

${ }^{38}$ A. KiDYBA, Prawo handlowe, Warszawa: Wydawnictwo C.H. Beck 2016, s. 97-100.
} 


\section{UWAGI KOŃCOWE}

Każda osoba fizyczna oraz prawna posiada dobra osobiste oraz prawo do ich ochrony. Powyższe zagadnienia prawne występowały zarówno w prawie rzymskim, w prawie obowiązującym na ziemiach polskich, począwszy od Księgi elbląskiej nazywanej pomnikiem prawa średniowiecznego, jak i w przepisach obowiązującego współcześnie m.in. Kodeksu cywilnego i prawa autorskiego. Występowanie regulacji dotyczących ochrony dóbr osobistych w każdej z tych epok historycznych dowodzi, że potrzeba chronienia dóbr istniała od zawsze. W związku z coraz bardziej dynamicznym rozwojem technologii zmieniły się nie tylko formy naruszenia dóbr, ale również powstały zupełnie nowe ich rodzaje. Oznacza to, że zagadnienie, jakim jest ochrona dóbr osobistych jest problemem uniwersalnym i dotyczy wszystkich osób, bez względu na epokę w której żyją.

Postulatem de lege ferenda, który nasuwa się po dokonaniu analizy obowiązujących przepisów prawa jest wprowadzenie definicji legalnej „dobra osobistego”. Włączenie takiego pojęcia do przepisów prawa powinno mieć charakter otwarty, tzn. powinno być skonstruowane w taki sposób, aby swoim zakresem mogło objąć jak najszersze znaczenie tego pojęcia i tym samym umożliwić sędziom jego interpretację w każdej indywidualnej sprawie. Stanowisko sugerujące, że wprowadzenie definicji legalnej tego pojęcia ograniczy luz decyzyjny należący do sędziów jest nietrafne. Nie chodzi tutaj bowiem o wprowadzenie katalogu zamkniętego dóbr osobistych chronionych przez prawo, a jedynie o wprowadzenie ogólnej definicji charakteryzującej to pojęcie. Pojęcie naruszenia dobra osobistego powinno być oceniane również na podstawie obiektywnych kryteriów, nie zaś wyłącznie na subiektywnym odczuciu poszkodowanego. Najbardziej racjonalnym rozwiązaniem mogłoby być wprowadzenie takiej definicji, która umożliwiałaby sędziom w sposób elastyczny orzekać o zasadności występowania w sprawie naruszenia danego dobra przez poszkodowanego. Poprzez różnorodne rozumienie samego pojęcia, jakim jest dobro osobiste, w obowiązującym stanie prawnym ciężko jest stwierdzić, czy pewne zachowanie będzie naruszeniem dobra osobistego czy też nie.

\section{BIBLIOGRAFIA}

\section{ŹRÓDŁA PRAWA}

Konstytucja Rzeczypospolitej Polskiej z dnia 2 kwietnia 1997 r., Dz. U. Nr 78, poz. 483. Ustawa z dnia 29 marca 1926 r. o prawie autorskiem, Dz. U. Nr 48, poz. 286. 
Ustawa z dnia 2 sierpnia 1926 r. o zwalczaniu nieuczciwej konkurencji, Dz. U. Nr 96, poz. 559.

Ustawa z dnia 18 lipca 1950 r. - Przepisy ogólne prawa cywilnego, Dz. U. Nr 34, poz. 311.

Ustawa z dnia 23 kwietnia 1964 r. - Kodeks cywilny, Dz. U. Nr 16, poz. 93.

Rozporządzenie Prezydenta Rzeczypospolitej z dnia 22 marca 1928 r. o ochronie wynalazków, wzorów i znaków towarowych, Dz. U. Nr 39, poz. 384.

Rozporządzenie Prezydenta Rzeczypospolitej z dnia 27 października 1933 r. - Kodeks zobowiązań, Dz. U. Nr 82, poz. 598.

\section{ORZECZNICTWO}

Wyrok Sądu Najwyższego z dnia 19 września 1968 r., sygn. akt II CR 291/68, OSNCPiUS 1969. Wyrok Sądu Najwyższego z dnia 25 maja 1977 r., sygn. akt I CR 159/77.

Wyrok Sądu Najwyższego z dnia 10 czerwca 1977 r., sygn. akt II CR 187/77.

Wyrok Sądu Najwyższego z dnia 25 października 1982 r., sygn. akt I CR 239/82

Wyrok Sądu Najwyższego z dnia 18 stycznia 1984 r., sygn. akt I CR 400/83, OSNC 184/11/195.

Wyrok Sądu Najwyższego z dnia 3 lutego 200 r., sygn. akt I CKN 969/98.

Wyrok Sądu Najwyższego z dnia 9 czerwca 2005 r., sygn. akt III CK 622/04.

Wyrok Sądu Najwyższego z dnia 29 października 2009 r., sygn. akt III CZP 79/09.

Wyrok Sądu Apelacyjnego w Katowicach z dnia 25 kwietnia 2018 r., sygn. akt I ACa 1056/17.

Wyrok Sądu Apelacyjnego w Warszawie z dnia 10 maja 2018 r., sygn. akt V ACa 753/17.

Wyrok Sądu Apelacyjnego w Warszawie z dnia 11 lipca 2018 r., sygn. akt V ACa 565/17.

Wyrok Sądu Apelacyjnego w Warszawie z dnia 11 października 2018 r., sygn. akt I ACa 387/18.

Wyrok Sądu Rejonowego Gdańsk-Południe w Gdańsku z dnia 29 czerwca 2017 r., sygn. akt I C $177 / 17$.

\section{LITERATURA}

BATORY Weronika: Stulecie rozwoju ochrony patentowej na ziemiach polskich - analiza historyczno-prawna od 1918 roku do okresu bieżącego, Polska Niepodległa 1918-2018. Księga rocznicowa z okazji 100 rocznicy odzyskania niepodległości, red. A. Wiśniewiski, Warszawa: Wydawnictwo Think \& Make 2018, s. 620-640.

CiseK Andrzej: Dobra osobiste i ich niemajątkowa ochrona w kodeksie cywilnym, Wrocław: Wydawnictwo Uniwersytetu Wrocławskiego 1989.

GRZYBOwSKI Stefan: Ochrona dóbr osobistych według przepisów ogólnych prawa cywilnego, Warszawa: Wydawnictwo Prawnicze 1957.

Kalus Stanisława: Osoby. Przesłanki ochrony, [w:] Kodeks cywilny. Komentarz. Tom I, red. M. Habdas, M. Fras, Warszawa: Wolters Kluwer 2018, s. 127-129.

KIDYBA Andrzej: Prawo handlowe, Warszawa: Wydawnictwo C.H. Beck 2016.

Puchata Agata: Pojęcie dóbr osobistych, [w:] Dobra osobiste, red. I. Lewandowska-Malec, Warszawa: Wydawnictwo C.H. Beck 2017, s. 25-40.

RATAJ Karolina: Ukształtowanie dóbr osobistych i ich historyczny rozwój, [w:] Dobra osobiste, red. I. Lewandowska-Malec, Warszawa: Wydawnictwo C.H. Beck 2017, s. 1-24.

SKIBA Natalia: Ochrona dóbr osobistych na gruncie polskiego prawa cywilnego, [w:] Dobra osobiste, red. I. Lewandowska-Malec, Warszawa: Wydawnictwo C.H. Beck 2017, s. 213-250.

SoBolewski Przemysław: Dobra osobiste, [w:] Kodeks cywilny. Komentarz. Tom I, red. K. Osajda, Warszawa: Wydawnictwo C.H. Beck 2013, s. 350-391.

Sut Paweł: Problem twórczej wykładni przepisów o ochronie dóbr osobistych, Państwo i Prawo 9 (1997), s. 26-38. 


\section{DOBRA OSOBISTE I ICH OCHRONA NA GRUNCIE KODEKSU CYWILNEGO}

\section{Streszczenie}

Celem niniejszego artykułu jest przybliżenie czytelnikowi problematyki dotyczącej ochrony dóbr osobistych zawartej w przepisach Kodeksu cywilnego. Praca prezentuje kształtowanie się instytucji ochrony dóbr osobistych na tle historycznym. Głównym przedmiotem badań jest analiza aktualnych przepisów prawa cywilnego odnoszących się do istoty pojęcia dobra osobistego oraz do roszczeń, jakie przysługują poszkodowanemu w przypadku ich naruszenia. W polskim ustawodawstwie nie występuje jedna definicja dobra osobistego, skutkiem czego pojęcie dobra osobistego wypracowane zostało przez przedstawicieli doktryny oraz orzecznictwo sądów. Dobra osobiste człowieka są jego prawami podmiotowymi, skutecznymi erga omnes. Ochrona dóbr występująca w Kodeksie cywilnym przysługuje w momencie zaistnienia bezprawnego zagrożenia ich naruszenia. W wyniku całościowej analizy powyższych zagadnień, postulatem autora jest wprowadzenie ogólnej definicji pojęcia dobra osobistego.

Słowa kluczowe: prawa podmiotowe; prawo cywilne; zadośćuczynienie; roszczenie; ochrona prawna

\section{PERSONAL RIGHTS AND THEIR PROTECTION UNDER THE CIVIL CODE}

\section{S u m m a r y}

The purpose of this article is to familiarize the reader with the issues concerning the protection of personal interests contained in the provisions of the Civil Code. The work presents the development of institutions for the protection of personal rights in a historical context. The main subject of the research is the analysis of current civil law provisions pertaining to the essence of the concept of personal good and to claims that are entitled to the aggrieved party in case of their violation. There is no single definition of personal good in the Polish legislation, which resulted in the concept of personal good being developed by the representatives of the doctrine and the judicial decisions of the courts. The personal rights of a man are his subjective rights, effective erga omnes. The protection of goods appearing in the Civil Code is vested in the moment of unlawful threat of their violation. As a result of a comprehensive analysis of the above issues, the postulate of the author is the introduction of a general definition of the concept of personal good.

Key words: subjective rights; civil law; compensation; claim; legal protection 